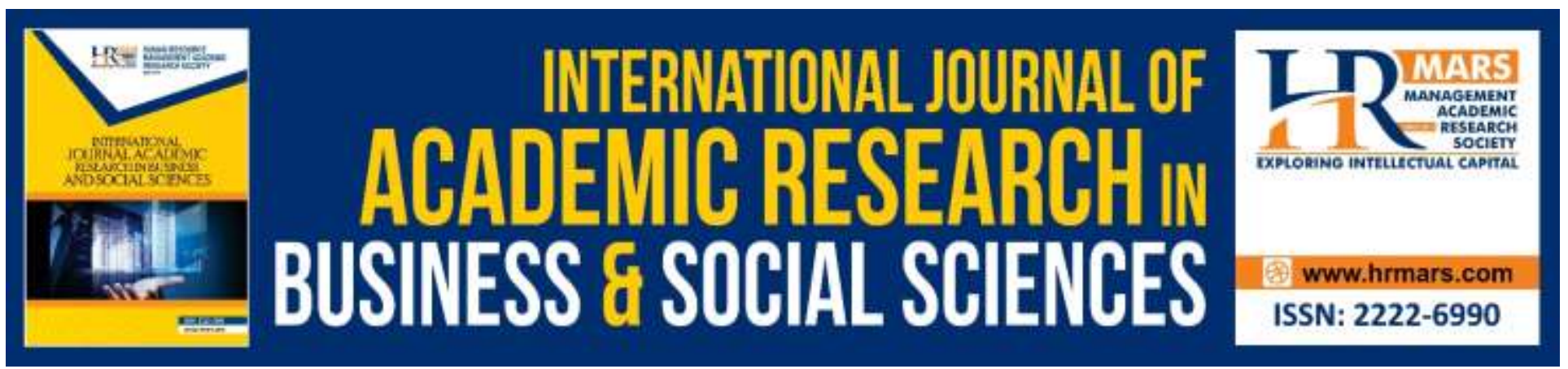

\title{
Social Desirability and Mentorship Influencing New Venture Creation by Women Entrepreneurs in India
}

Jyoti Choudhary, Haslinda Hashim, Ho Jo Ann, Murali Sambasivan

To Link this Article: http://dx.doi.org/10.6007/IJARBSS/v10-i5/7253

DOI:10.6007/IJARBSS/v10-i5/7253

Received: 25 March 2020, Revised: 29 April 2020, Accepted: 02 April 2020

Published Online: 28 May 2020

In-Text Citation: (Choudhary et al., 2020)

To Cite this Article: Choudhary, J., Hashim, H., Ann, H. J., \& Sambasivan, M. (2020). Social Desirability and Mentorship Influencing New Venture Creation by Women Entrepreneurs in India. International Journal of Academic Research in Business and Social Sciences, 10(5), 830-842.

Copyright: (c) 2020 The Author(s)

Published by Human Resource Management Academic Research Society (www.hrmars.com)

This article is published under the Creative Commons Attribution (CC BY 4.0) license. Anyone may reproduce, distribute, translate and create derivative works of this article (for both commercial and non-commercial purposes), subject to full attribution to the original publication and authors. The full terms of this license may be seen at: http://creativecommons.org/licences/by/4.0/legalcode

Vol. 10, No. 5, 2020, Pg. 830 - 842

http://hrmars.com/index.php/pages/detail/IJARBSS

JOURNAL HOMEPAGE

Full Terms \& Conditions of access and use can be found at http://hrmars.com/index.php/pages/detail/publication-ethics 


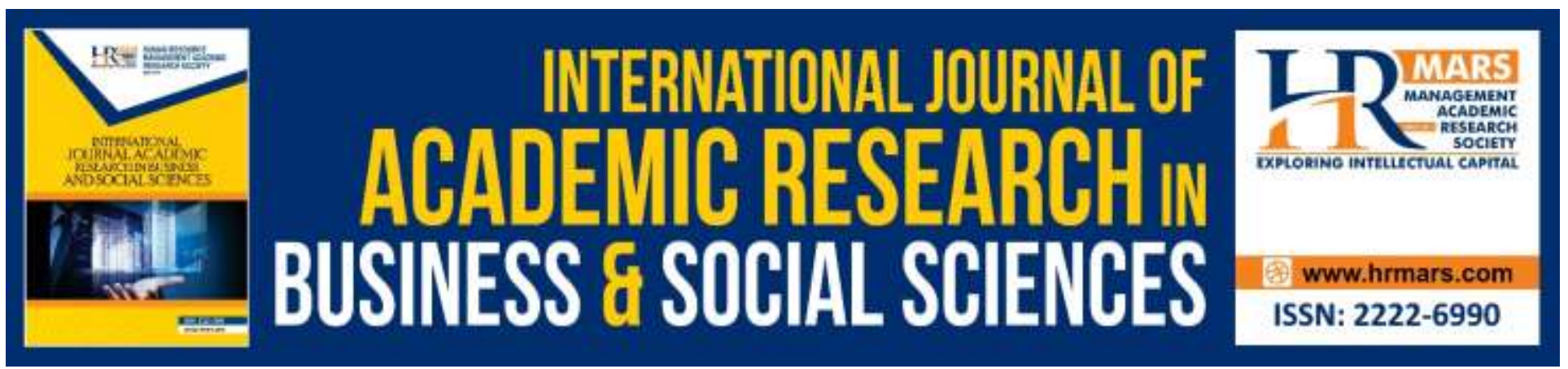

\title{
Social Desirability and Mentorship Influencing New Venture Creation by Women Entrepreneurs in India
}

\author{
Jyoti Choudhary ${ }^{1}$, Haslinda Hashim², Ho Jo Ann³, Murali \\ Sambasivan ${ }^{4}$
}

School of Graduate studies, University Putra Malaysia, 43400 Serdang, Selangor ${ }^{1}$, Department of Management and Marketing, Faculty of Economics and Management, University Putra Malaysia, 43400 Serdang, Selangor ${ }^{2 \& 3}$, Taylors University College, 47500 Subang Jaya, Selangor Darul Ehsan ${ }^{4}$

\begin{abstract}
Women entrepreneurs in developing countries like India find opportunity recognition challenging thereby, preventing them from creating new ventures, particularly SMEs. Social desirability and mentorship have been recognised an important dimension of social support for women entrepreneurs. Environments, where the social desirability of women entrepreneurship is higher, can encourage entrepreneurship as a career path for women. Similarly, external knowledge provided by experienced mentor can be one of the most relevant sources of information for women to recognise opportunities and exploit it by creating new ventures. Mentorship becomes more important for women considering they have less networks, awareness and social capital. However, little knowledge has been advanced to investigate their influence on mentorship and social desirability opportunity recognition and creation of women owned SMEs in India. Presence of these support factors can encourage women entrepreneurship whereas lack of them can discourage women to pursue entrepreneurship. Furthermore, there is a dearth of studies examining the mediating role of opportunity recognition between social desirability, mentorship and venture creation. Based on the synthesis of vast amount of prior literature, a conceptual model of venture creation is developed to explain the relationships amongst the constructs under study. Consequently, testable propositions are proposed for future empirical examinations. The proposed relationships are further explained with the support of Institutional theory and Resource based theory.
\end{abstract}

Keywords: Women Entrepreneurs, Social Support, Mentorship, Social Desirability, Opportunity Recognition, New Venture Creation.

\section{Introduction}

To create a new venture, the most valuable ability that a entrepreneurs must possess, is the ability to recognize an opportunity and choose accordingly (Santos, Caetano, Baron, \& Curral, 2015; Shane \& Nicolaou, 2015). In the next step, entrepreneur evaluates these opportunities and decides to exploit them. Thus, opportunity recognition and opportunity exploitation through a decision to launch a venture have been identified as the first two stages of the entrepreneurship process 
INTERNATIONAL JOURNAL OF ACADEMIC RESEARCH IN BUSINESS AND SOCIAL SCIENCES Vol. 10, No. 5, May, 2020, E-ISSN: 2222-6990 @ 2020 HRMARS

(Brockman, 2014; Choi \& Shepherd, 2004). Despite the enthusiasm displayed by Indian women to enter entrepreneurship, they face many challenges which act as a hindrance in opportunity recognition and starting up a business (Agarwal \& Lenka, 2016). Women entrepreneurs are subjected to many limitations that impede their functioning. The limitations include poor self-image of women; discriminating treatment; faulty socialisation; lack of social acceptance; unjust social, economic, and cultural system and susceptibility to a negative attitude (Arruda, Nogueira, \& Cozzi, 2015; Fielden \& Davidson, 2012; Rubio-Bañón \& Esteban-Lloret, 2016; Wellalage \& Locke, 2017). Moreover, coming from a conservative and patriarchal society, women in India have to conform to the standards laid down by society which restricts them from exploring opportunities and creating a venture. The qualities required to be a successful entrepreneur are in contrast with the traditional roles set up by society (Okafor \& Mordi, 2010). This is further compounded by lack of role models and mentors who can guide them through the entrepreneurial journey (Kyrgidou \& Petridou, 2013). Without, the social support, women decide either not to pursue entrepreneurship as a career or they decide to start it a micro level out of necessity. Consequently, women entrepreneurship in India constitute only 13\%of the total entrepreneurs and the women creating SMEs are even lower (Samantroy \& Tomar, 2018). Despite, the acknowledgement of the fact that without boosting women's economic participation in SMEs, it will be challenging for India to achieve 2030 Agenda for Sustainable Development Goals (SDGs),(Anthony, Arthur, Nagarajan, Wood, \& Ayyagari, 2015; Kent Baker, Kumar, \& Rao, 2017). There is dearth of research conducted on women entrepreneurship in SMEs in India (McKevitt \& Marshall, 2015). Thus, the study of factors that influence rate of creating new ventures, particularly by women in SMEs has become an important issue on the agendas of economists, researchers and politicians in most countries.

Institutional support, in the form of social support has always been accepted in literature as an integral part of entrepreneurship. Social support is social resources that a person perceive to be available or that are actually provided to them by non-professionals in the context of both formal support groups and informal helping relationship (Markussen \& Røed, 2017; Martin, Platis, Malita, \& Ardeleanu, 2011). Cluster of researches have suggested mentorship and social desirability as important social support in the choice of entrepreneurial activity for women (Eesley \& Wang, 2017; Muralidharan \& Pathak, 2017). Social desirability in entrepreneurial research is considered as the commonly held perceptions about rewards societies place on the career choice of entrepreneurship (Păunescu, Popescu, \& Duennweber, 2018). A national context with high social desirability for entrepreneurship will be a productive ground for nascent entrepreneurs to take advantage of the opportunities and enter the market (Muralidharan \& Pathak, 2017). The social desirability of an entrepreneurial career has been shown to differ in different countries; some countries assist and promote entrepreneurship, while others discourage it by making it difficult to pursue (Păunescu et al., 2018; Urban \& Kujinga, 2017). Discouragement could be due to traditions, norms, stereotypes and beliefs existing in the society. Women in patriarchal societies find it hard to gain acceptance from society of their choice of an entrepreneurial career (Păunescu, Popescu, \& Duennweber, 2018); Muralidharan \& Pathak, 2017). Although India is a conservative and patriarchal society, it is going through major transformation in terms of outlook of society towards career women (Sivanesan, 2014). However, the influence of social desirability on opportunity recognition and new venture creation has not been empirically tested in the context of women owned SMEs. Similarly, mentorship which is defined as a developmentally oriented interpersonal relationship between a more 
experienced individual (mentor) and a less experienced individual,(mentee) has been accepted to fosters the discovery of opportunities and strengthening business for early-stage entrepreneurs (Klyver \& Schøtt, 2011; Pruthi, 2014). Mentorship is more important for women in comparison to men as they have less networks, awareness, social capital and confidence (Hani, Rachmania, Setyaningsih, \& Putri, 2012; Jennings \& Brush, 2013a). With entrepreneurial culture thriving in India, increase in the number of successful entrepreneurs and gradual transformation in the attitude of society towards women career choices, there is a high possibility that these factors will significantly influence women entrepreneurs (Arruda et al., 2015; Jha, 2018). However dearth of literature on investigating the influence of social desirability and mentorship on women entrepreneurs in developing countries, particularly SMEs, makes it important to research the influence of social support on women owned SMEs in India (Joshi, 2015; Pettersson, Ahl, Berglund, \& Tillmar, 2017). Furthermore, very little efforts have been made to examine the mediating role of opportunity recognition between social factors and new venture creation through the (Castaño, Méndez, \& Galindo, 2015; Kuckertz, Kollmann, Krell, \& Stöckmann, 2017; Nikraftar \& Hosseini, 2016). To the researchers' best knowledge, no study has investigated the relationships amongst social desirability, opportunity recognition and new venture creation in context of women entrepreneurs owning SMEs in a single integrated framework. This study therefore intends to address this gap by proposing opportunity recognition as a mediator to investigate the relationships between social factors, opportunity recognition and venture creation by women entrepreneurs.

\section{Research Objectives}

The main objective of this research is to study and understand the influence of social desirability and mentorship on the opportunity recognition and venture creation by women entrepreneurs in India.

RO1: To examine the influence of social desirability on opportunity recognition and new venture creation by women entrepreneurs in India.

RO2: To examine the influence of mentorship on opportunity recognition and new venture creation by women entrepreneurs in India.

RO3: To determine the mediating effect of opportunity recognition between social desirability, mentorship and new venture creation among women entrepreneurs in India.

\section{Definition and Overview of Women Entrepreneurs in India}

Women entrepreneurs are women that participate in total entrepreneurial activities and assume the risks involved in combining resources in a unique way to take advantage of the opportunity identified in their immediate environment through the production of goods and services (Moses, Chinonye \& Mordi, 2010). In the Indian context, participation of women as entrepreneurs commenced from 1970s onwards. Historical evidence suggests that in India, representation of women entrepreneurs was abysmally low during both the colonial and post-independence era, much attributed to the social setup and the role entrusted upon women. However, it has begun to increase due to increased education and awareness among women, advent of technology and thriving entrepreneurial culture in India.(Arruda et al., 2015; Kungwansupaphan \& Leihaothabam, 2016). Thus the presence of women entrepreneurs is evident in all fields ranging from, traditional papad (Indian snack), pickles and powder businesses to manufacturing, trading and IT enabled services (Kungwansupaphan \& Leihaothabam, 2016; Sharma, 2013). Women are coming out of their role which was laid back and 
INTERNATIONAL JOURNAL OF ACADEMIC RESEARCH IN BUSINESS AND SOCIAL SCIENCES

Vol. 10, No. 5, May, 2020, E-ISSN: 2222-6990 @ 2020 HRMARS

which related with their father, brother or husband (Arruda et al., 2015). However, majority of women operate in micro sector and there is a persistent gender gap.

\section{New Venture Creation}

New venture creation is a process of planning, organizing, and establishing new organizations which has been an important area of interest for entrepreneurship researchers (Gartner, 1995). New ventures are crucial drivers of economic development and industry evolution. According to Baron (2015) venture creation process encompasses a) entrepreneurial intent, b) opportunity search c) the decision to exploit it by new venture creation d) sustaining it for a period of time. Based on these reflections entrepreneurial process is viewed as the succession of the opportunity-related process (recognition - evaluation - exploitation). Thus, opportunity recognition forms the basis of new venture creation.

\section{Opportunity Recognition}

According to Shane and Venkatraman, entrepreneurship is first of all about opportunities. "Without an opportunity, there is no entrepreneurship". Opportunity recognition is defined as a process whereby individuals identify, recognize, and discover potential opportunities to create and develop new ventures (Wang, Ellinger, \& Wu, 2013). Since people need to identify opportunities to be entrepreneurs, skill at opportunity identification increases the probability that a person will become an entrepreneur. Women entrepreneurs face numerous challenges in recognising opportunities and creating business due to lack of social support. Various social factors have been identified that promote women entrepreneurship. Amongst them the influence of social desirability and mentorship has been accepted as crucial factors for women entrepreneurs, considering women have less social capital, networks and freedom to pursue their decisions. Social desirability of entrepreneurship career for women could give them the confidence to pursue their entrepreneurial passion (Muralidharan \& Pathak, 2017; Ritchie, 2016).Likewise, knowledge gained from experienced mentor can increase their knowledge and awareness, thereby making them ready to recognize opportunity. Thus, the literature suggests to investigate the relationship between social desirability, mentorship, opportunity recognition and new venture creation in context of women entrepreneurs (Hassan, Osman, \& Rashid, 2011; Jennings \& Brush, 2013b).

\section{Relationship between Social Desirability and Opportunity Recognition among Women Entrepreneurs}

Social desirability in entrepreneurial research is defined as a body of commonly held perceptions about the rewards societies place on the career choice of entrepreneurship (Muralidharan \& Pathak, 2017). The level of desirability is expected to affect all aspects of entrepreneurship. All other things being equal, the higher it is, the more society will reward entrepreneurs, and the more entrepreneurial behaviour will be the source of psychic rewards, generated by the respect the activity generates. A national context with high social desirability for entrepreneurship is more conducive and open to legitimising entrepreneurship as a career path for individuals. It is more open to sharing risks and providing social capital and valuable information, each of these is vital for entrepreneurs' initiatives in the country. In such context, entrepreneurs are likely to be rewarded with wider media coverage leading to higher visibility of their impact on the economy (Jha, 2018; Neumeyer \& Santos, 2017). Factors such as public acceptance and community create an enterprise culture that enables 
INTERNATIONAL JOURNAL OF ACADEMIC RESEARCH IN BUSINESS AND SOCIAL SCIENCES

Vol. 10, No. 5, May, 2020, E-ISSN: 2222-6990 ㄷ 2020 HRMARS

entrepreneurs to take reasonable risks and create new ventures (Hasan \& Almubarak, 2016; SuárezOrtega \& Gálvez-García, 2017).

Institutional theory also postulates that support from the informal sources such as society can be of considerable importance to entrepreneur (Urban \& Kujinga, 2017). For women social desirability in patriarchal society like India, holds more importance as women conform to the norms, and culture prevailing in the society. Their choice of career is dependent on the approval from the community, family and peers. The conditioning and upbringing of women makes her conform to the approval of society, more than men (Hasan \& Almubarak, 2016; Pareek \& Bagrecha, 2017; Pruthi, 2014). A national perspective with elevated social desirability for entrepreneurship will, therefore, be a prolific ground for women entrepreneurs to benefit from the opportunities and enter the market with innovative offerings (Muralidharan \& Pathak, 2017). Thus, the authors propose:

Preposition 1: There is a positive relationship between social desirability and opportunity recognition among women entrepreneurs.

\section{Relationship between Mentorship and Opportunity Recognition among Women Entrepreneurs}

External knowledge provided by individuals with recent business start-up experience in the entrepreneur's environment can be one of the most relevant sources of social support for early-stage entrepreneurs. It nurtures the discovery of opportunities as well as their exploitation and identification (Kyrgidou \& Petridou, 2013; Sarri, 2011). As experienced entrepreneurs are expected to have higher knowledge, beginner entrepreneurs can take experienced entrepreneurs as their mentors and benefit from their experience and knowledge in recognising business opportunities. Such relations may directly increase the opportunity recognition capacity (Castaño et al., 2015). Mentors are also likely to be unique in terms of resource networks. They are likely to know some early-stage investors. An introduction and recommendation from an experienced mentor are likely to carry greater weight and thus social influence among investors (Kyrgidou \& Petridou, 2013; McKevitt \& Marshall, 2015). Thus, there is a link between mentorship and entrepreneurship.

Institutional support in form of mentorship might be more significant for women entrepreneurs considering they have less social capital and access to information (Eesley \& Wang, 2017; Naguib \& Jamali, 2015). A mentor can encourage women to follow her success path by advising and guiding them through her own experiences. Mentoring can help many women overcome their own self-limiting beliefs and mindsets, which can hinder them in aspiring entrepreneurial roles. It can provide them with increased awareness, knowledge and confidence to recognise opportunities. Hence based the findings of previous studies authors propose the following:

Preposition 2: There is a positive relationship between mentorship and opportunity recognition among women entrepreneurs 
INTERNATIONAL JOURNAL OF ACADEMIC RESEARCH IN BUSINESS AND SOCIAL SCIENCES Vol. 10, No. 5, May, 2020, E-ISSN: 2222-6990 @ 2020 HRMARS

Relationship between Social Desirability and New Venture Creation among Women Entrepreneurs Another social support that can encourage women entrepreneurship is social desirability. Institutional theory postulates that informal support from society, in form of placing a high value on the formation of new ventures, could encourage more individuals to choose entrepreneurial path (Kazumi \& Kawai, 2017; Păunescu et al., 2018). All other things being equal, the more the society applaud and celebrate success of women entrepreneurs, more women will be encouraged to create new ventures (Niethammer, 2013). It is established that there is no gap between men's and women's capabilities. Women are prevented from participating in entrepreneurship not due to a lack of entrepreneurial skills but due to a lack of societal confidence in their abilities (Hossain, Jahangir, \& Nur-Al-Ahad, 2018). However, in last few years, there is a positive shift in Indian society towards the career choices made by women. Conservative and stereotyped approach of the society towards women, which forced them either not to pursue entrepreneurship, or at the most pursue it at micro level is changing (Joshi, 2015; Kent Baker et al., 2017; Sivanesan, 2014). Presence of women entrepreneurs is evident in SMEs (Singer, Amoros, \& Arreola, 2015). From the above discussion, it can be concluded that social support via acceptance of women's career choice as entrepreneurs increases the likelihood of increase in women owned SMEs. women entrepreneurs engaging in entrepreneurship and creating new ventures. Hence, based on the institutional theory and evidences from the literature we propose that:

Proposition 3 - There is a positive relationship between social desirability and new venture creation among women entrepreneurs.

\section{Relationship between Mentorship and New Venture Creation among Women Entrepreneurs}

Mentors are drawn from social groups that share professional traits with the mentees. Given that norms and the codes of conduct governing behaviours within the start-up community are often tacit and unwritten, direct guidance from experienced entrepreneurs could be important for entrepreneurs in learning the ropes (Roundy, 2017). In addition, mentors are also likely to be unique in terms of resource networks. Previous studies suggest that once opportunities are recognized and they have to be enacted, mentee, often did not have the experience or competence to take action alone (McKevitt \& Marshall, 2015; Sarri, 2011). Mentorship can facilitate this by reducing the constraints associated with the liabilities of newness. Referrals to pertinent sources of information and people like venture capitalists, graphic designers, patent attorneys and/or potential customers could help entrepreneurs, particularly women, to overcome newness and enable their venture to appear reliable in the presence of customers, government agencies and financers (Kazumi \& Kawai, 2017; Salimath \& Cullen, 2010). Besides this preventing failure, is the critical success factor for small firms (Ribes-Giner, Moya-Clemente, Cervelló-Royo, \& Perello-Marin, 2018). Women lack competencies to create and sustain the business more than men (Mitchelmore \& Rowley, 2013) Mentorship can reduce the risk of business failure by providing continuous guidance to women entrepreneurs and thus increasing the chance of survival of ventures created (McKevitt \& Marshall, 2015). Successful entrepreneurs historically have had entrepreneurs as mentors. Thus, mentorship seems to have significant relationship with venture creation. Thus, we propose that:

Proposition 4 There is a positive relationship between mentorship and new venture creation among women entrepreneurs. 
INTERNATIONAL JOURNAL OF ACADEMIC RESEARCH IN BUSINESS AND SOCIAL SCIENCES

Vol. 10, No. 5, May, 2020, E-ISSN: 2222-6990 @ 2020 HRMARS

\section{Mediating Role of Opportunity Recognition}

Existing literatures have established that venture creation is a consequence of an entrepreneur's opportunity recognition ability. Since support factors such as social desirability and mentorship can encourage women to recognise opportunity (Eesley \& Wang, 2017; Wei \& Wang, 2014), we argue that opportunity recognition mediates the relationship between social desirability, mentorship and new venture creation. To the best of the researcher's knowledge, no prior studies have investigated the mediation effect of opportunity recognition on the relationship of these factors with new venture creation, particularly in the context of women-owned SMEs in India. Previous researchers have examined this relationship on the performance of established ventures (Farr-Wharton \& Brunetto, 2007; Sambasivan, Abdul, \& Yusop, 2009). Thus, we propose that:

Proposition 5- Opportunity recognition mediates between social desirability and new venture creation

Proposition 6- Opportunity recognition mediates between mentorship and new venture creation

\section{Research Framework}

Based on the review of literature and objectives of the study as explained in earlier sections, a conceptual framework (see figure 1) has been developed to show the relationships amongst mentorship and social desirability, opportunity recognition and new venture creation. The current study, drawing from the Resource Based Theory (RBT) and Institutional theory argue that the mentorship and social desirability would enhance the opportunity recognition of women entrepreneurs and will thereby increase the creation of SMEs by women entrepreneurs in India. In this regard, opportunity recognition could mediate the relationship between social factors and new venture creation within the SMEs in India. The framework has two exogenous variables, one exogenous/endogenous variable and one endogenous variable.

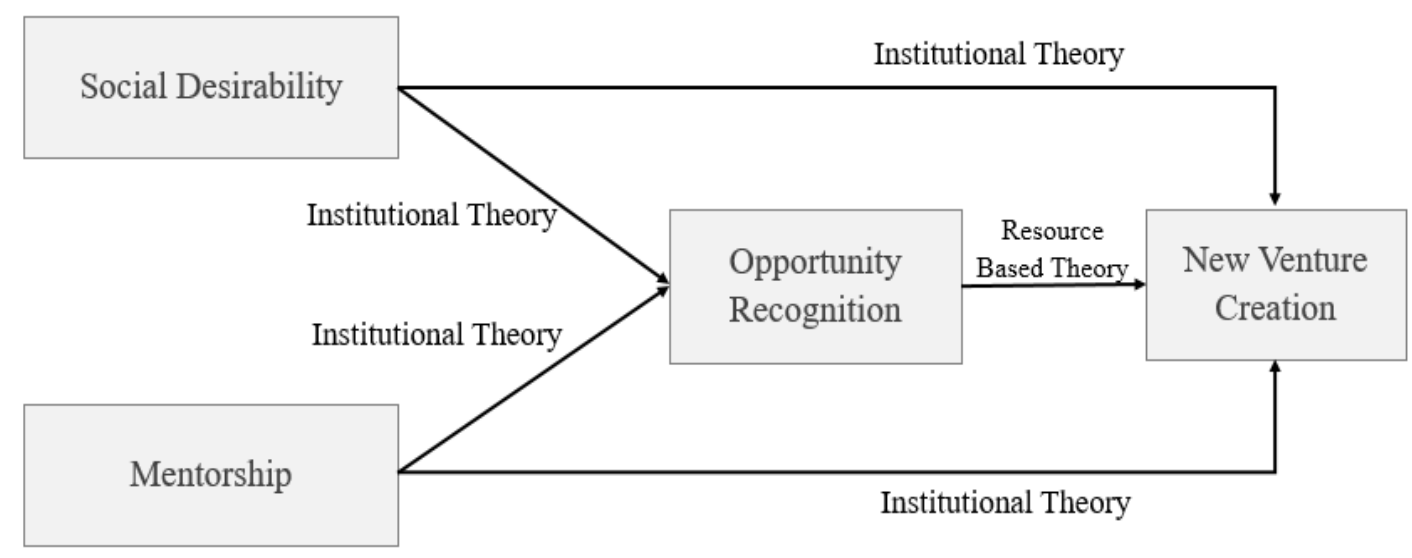

Figure: 1 Proposed conceptual framework linking social desirability and mentorship with opportunity recognition and new venture creation

\section{Conclusion/Implications}


With only modest attempts made by researchers to examine the relationships between social desirability, mentorship, opportunity recognition and new venture creation in a single framework, this study set out to achieve two major objectives. The first objective is to examine the possible direct effects of social desirability and mentorship on opportunity recognition and new venture creation. Secondly, to investigate the possible mediating role of opportunity recognition between social desirability, mentorship and new venture creation relationship. The study hopes to contribute to the current discussions on the important role of social support on opportunity recognition and venture creation by women entrepreneurs, particularly women owned SMEs. Practically, the study hopes to draw the attention of policy makers on the need to increase mentorship forums and recognising and rewarding the achievements of women entrepreneurs to encourage more women participation in entrepreneurship. Also, the empirical testing of this proposed integrated model could provide empirical evidence particularly to government, women associations society on the role of mentorship and social desirability for women entrepreneurs.

\section{Future Research Direction}

In recent years, the research conducted in the development and validation of measurements intended to measure constructs like new venture creation, opportunity recognition and social factors have developed rapidly. However, despite the growing research in this area, more studies are required to investigate these constructs in different context where women face the same problems. This study only focused on social factors like social desirability and mentorship. It did not take into account other institutional factors like; political, economic, environmental, and technological (Adomako, Danso, \& Ampadu, 2015; Fuentelsaz, González, \& Maicas, 2018; Salimath \& Cullen, 2010), which can also influence entrepreneurship. Based on this conceptual paper, the authors recommended some substantial future directions aiming on identifying other factors that helps in increasing new venture creation by women entrepreneurs in SMEs in developing countries like India, where inequality among men and women is considerably high. Furthermore, this study only took into consideration opportunity recognition. Influence of social factors on another aspects opportunity discovery and opportunity creation could be another field of research in context of women entrepreneurship. Additionally, since extent of societal desirability and structure mentorship program varies among countries, these factors can be studied in other nations.

\section{References}

Adomako, S., Danso, A., \& Ampadu, E. (2015). Institutional outlook of the entrepreneurial climate in Ghana. International Journal of Social Economics, 42(6), 566-582. https://doi.org/10.1108/IJSE-09-2013-0206

Agarwal, S., \& Lenka, U. (2016). An exploratory study on the development of women entrepreneurs: Indian cases. Journal of Research in Marketing and Entrepreneurship, 18(2). https://doi.org/10.1108/JRME-04-2015-0024

Anthony, L., Arthur, S., Nagarajan, G., Wood, D., \& Ayyagari, M. (2015). The Role Of Micro, Small, And Medium Enterprises In Economic Growth: A Cross-Country Regression Analysis. In The IRIS Center, University Research Corporation International.

Arruda, C., Nogueira, V. S., \& Cozzi, A. (2015). Entrepreneurship in BRICS. https://doi.org/10.1007/978-3-319-11412-5.

Baker, K. H., Kumar, S., \& Rao, P. (2017). Financing preferences and practices of Indian SMEs. Global 
INTERNATIONAL JOURNAL OF ACADEMIC RESEARCH IN BUSINESS AND SOCIAL SCIENCES

Vol. 10, No. 5, May, 2020, E-ISSN: 2222-6990 @ 2020 HRMARS

Finance Journal, (May), 1-16. https://doi.org/10.1016/j.gfj.2017.10.003

Brockman, B. K. (2014). Entrepreneurial alertness in opportunity identification and opportunity development. Journal of Business and Entrepreneurship, 26, 27-44. Retrieved from http://search.proquest.com/docview/1634881485 ?accountid $=44542$.

Castaño, M.-S., Méndez, M.-T., \& Galindo, M.-Á. (2015). The effect of social, cultural, and economic factors on entrepreneurship. Journal of Business Research, 68(7), 1496-1500. https://doi.org/10.1016/j.jbusres.2015.01.040

Choi, Y. R., \& Shepherd, D. A. (2004). Entrepreneurs' decisions to exploit opportunities. Journal of Management, 30, 377-395. https://doi.org/10.1016/j.jm.2003.04.002

Eesley, C., \& Wang, Y. (2017). Social influence in career choice: Evidence from a randomized field experiment on entrepreneurial mentorship. Research Policy, 46(3), 636-650. https://doi.org/10.1016/j.respol.2017.01.010

Farr-Wharton, R., \& Brunetto, Y. (2007). Women entrepreneurs, opportunity recognition and government-sponsored business networks: A social capital perspective. Women in Management Review, 22(3), 187-207. https://doi.org/10.1108/09649420710743653

Fielden, S., \& Davidson, M. J. (2012). BAME women business owners: how intersectionality affects discrimination and social support. Gender in Management: An International Journal, 27(8), 559-581. https://doi.org/10.1108/17542411211279733

Fuentelsaz, L., González, C., \& Maicas, J. P. (2018). Formal institutions and opportunity entrepreneurship. The contingent role of informal institutions. BRQ Business Research Quarterly. https://doi.org/10.1016/j.brq.2018.06.002

Gartner, W. B. (1995). The Describing Framework for Conceptual Creation Venture Phenomenon of New Venture Creation. Academy of Management Review, 10(4), 696-706. https://doi.org/10.1177/026327602761899255

Global Entrepreneurship Monitor 2017-18 India ReportSh ukla, S., Ismail, M., Navniit, P., Chatwal, S., Bharti, P., Kumar, A., \& Madhya, D. (n.d.). Global Entrepreneurship Monitor 2017-18 India Report.

Hani, U., Rachmania, I. N., Setyaningsih, S., \& Putri, R. C. (2012). Patterns of Indonesian Women Entrepreneurship. Procedia Economics and Finance, 4(Icsmed), 274-285. https://doi.org/10.1016/S2212-5671(12)00342-5

Hasan, F. S. M. ., \& Almubarak, M. M. S. (2016). Factors influencing women entrepreneurs' performance in SMEs. World Journal of Entrepreneurship, Management and Sustainable Development, 12(2), 82-101. https://doi.org/10.1108/wjemsd-09-2015-0037

Hassan, M., Osman, M., \& Rashid, M. A. (2011). Market Orientation - A Missing Link to Successful Women Entrepreneurship in Developing Countries : A Conspectus of Literature. 3(4), 232237.

Holienka, M., Jančovičová, Z., \& Kovačičová, Z. (2016). Drivers of Women Entrepreneurship in Visegrad Countries: GEM Evidence. Procedia - Social and Behavioral Sciences, 220(March), 124-133. https://doi.org/10.1016/j.sbspro.2016.05.476

Hossain, J., Jahangir, N., \& Nur-Al-Ahad, M. (2018). A Study on Female Entrepreneurs in Malaysia. Business Ethics and Leadership, 2(3), 67-73. https://doi.org/10.21272/bel.2(3).67-73.2018

Jennings, J. E., \& Brush, C. G. (2013a). Research on Women Entrepreneurs : Challenges to (and from) the Broader Entrepreneurship Literature? Academy of Management Annals, 7(1), 663-715.

Jennings, J. E., \& Brush, C. G. (2013b). Research on Women Entrepreneurs : Challenges to (and from) 
INTERNATIONAL JOURNAL OF ACADEMIC RESEARCH IN BUSINESS AND SOCIAL SCIENCES

Vol. 10, No. 5, May, 2020, E-ISSN: 2222-6990 @ 2020 HRMARS

the Broader Entrepreneurship Literature? Academy of Management Annals, 7(1), 663-715.

Jha, S. K. (2018). Entrepreneurial ecosystem in India: Taking stock and looking ahead. IIMB Management Review, 30(2), 179-188. https://doi.org/10.1016/j.iimb.2018.04.002

Joshi, S. (2015). Service sector statistics in India: problems and way forward. World Journal of Science, Technology and Sustainable Development, 12(2), 148-154. https://doi.org/10.1108/WJSTSD03-2015-0014

Palak, K., \& Kirti, V. (2016). Role of Entrepreneurship in Indian Economy. Tactfull Management, 4(4), 1-10. https://doi.org/10.9780/23197943

Kazumi, T., \& Kawai, N. (2017). Institutional support and women's entrepreneurial self-efficacy. Asia Pacific Journal of Innovation and Entrepreneurship, 11(3), 345-365. https://doi.org/10.1108/apjie-12-2017-041

Klyver, K., \& Schøtt, T. (2011). How Social Network Structure Shapes Entrepreneurial Intentions? 1(1), 3-19.

Kuckertz, A., Kollmann, T., Krell, P., \& Stöckmann, C. (2017). Understanding, differentiating, and measuring opportunity recognition and opportunity exploitation. International Journal of Entrepreneurial Behavior \& Research, 23(1), 78-97. https://doi.org/10.1108/IJEBR-12-20150290

Kungwansupaphan, C., \& Leihaothabam, J. K. S. (2016). Capital factors and rural women entrepreneurship development. Gender in Management: An International Journal, 31(3), 207-221. https://doi.org/10.1108/GM-04-2015-0031

Kyrgidou, L. P., \& Petridou, E. (2013). Developing women entrepreneurs' knowledge, skills and attitudes through e-mentoring support. Journal of Small Business and Enterprise Development, 20(3), 548-566. https://doi.org/10.1108/JSBED-04-2013-0061

Markussen, S., \& Røed, K. (2017). The gender gap in entrepreneurship - The role of peer effects. Journal of Economic Behavior and Organization, 134(201336), 356-373. https://doi.org/10.1016/j.jebo.2016.12.013

Martin, C., Platis, M., Malita, L., \& Ardeleanu, M. (2011). The role of EMENTORING and social media for developing the entrepreneurship competences. Procedia - Social and Behavioral Sciences, 15, 947-951. https://doi.org/10.1016/j.sbspro.2011.03.218

McKevitt, D., \& Marshall, D. (2015). The legitimacy of entrepreneurial mentoring. International Journal of Entrepreneurial Behavior \& Research, 21(2), 263-280. https://doi.org/10.1108/IJEBR-05-2014-0089

Mitchelmore, S., \& Rowley, J. (2013). Entrepreneurial competencies of women entrepreneurs pursuing business growth. Journal of Small Business and Enterprise Development, 20(1), 125142. https://doi.org/10.1108/14626001311298448

Moses, Chinonye, \& Mordi, C. (2010). Women Entrepreneurship Development in Nigeria: the Effect of Environmental Factors. BULETINUL Universitatii Petrol- Gaze Din Ploie ti, 62(4), 43-52.

Muralidharan, E., \& Pathak, S. (2017). Informal institutions and international entrepreneurship. International Business Review, 26(2), 288-302. https://doi.org/10.1016/j.ibusrev.2016.07.006

Naguib, R., \& Jamali, D. (2015). Gender in Management: An International Journal Female entrepreneurship in the UAE: a multi-level integrative lens Female entrepreneurship in the UAE: a multi-level integrative lens. An International Journal An International Journal Iss Gender in Management An International Journal, 30(4), 135-161. 
INTERNATIONAL JOURNAL OF ACADEMIC RESEARCH IN BUSINESS AND SOCIAL SCIENCES

Vol. 10, No. 5, May, 2020, E-ISSN: 2222-6990 @ 2020 HRMARS

https://doi.org/10.1108/GM-12-2013-0142

Neumeyer, X., \& Santos, S. C. (2017). Sustainable business models, venture typologies, and entrepreneurial ecosystems: A social network perspective. Journal of Cleaner Production. https://doi.org/10.1016/j.jclepro.2017.08.216

Niethammer, C. (2013). Women, Entrepreneurship and the Opportunity to Promote Development and Business. The 2013 Brookings Blum Roundtable Policy Briefs, 31-39.

Nikraftar, T., \& Hosseini, E. (2016). Factors affecting entrepreneurial opportunities recognition in tourism small and medium sized enterprises. Tourism Review, 71(1), 6-17. https://doi.org/10.1108/TR-09-2015-0042

Okafor, C., \& Mordi, C. (2010). Women Entrepreneurship Development in Nigeria : the Effect of Environmental Factors. LXII(4).

Pareek, P., \& Bagrecha, C. (2017). A Thematic Analysis of the Challenges and Work-Life Balance of Women Entrepreneurs Working in Small-Scale Industries. Vision, 21(4), 461-472. https://doi.org/10.1177/0972262917739181

Păunescu, C., Popescu, M. C., \& Duennweber, M. (2018). Factors determining desirability of entrepreneurship in Romania. Sustainability (Switzerland), 10(11), 1-22. https://doi.org/10.3390/su10113893

Pettersson, K., Ahl, H., Berglund, K., \& Tillmar, M. (2017). In the name of women? Feminist readings of policies for women's entrepreneurship in Scandinavia. Scandinavian Journal of Management, 33(1), 50-63. https://doi.org/10.1016/j.scaman.2017.01.002

Pruthi, S. (2014). Social ties and venture creation by returnee entrepreneurs. International Business Review, 23, 1139-1152. https://doi.org/10.1016/j.ibusrev.2014.03.012

Ribes-Giner, G., Moya-Clemente, I., Cervelló-Royo, R., \& Perello-Marin, M. R. (2018). Domestic economic and social conditions empowering female entrepreneurship. Journal of Business Research. https://doi.org/10.1016/j.jbusres.2017.12.005

Ritchie, H. A. (2016). Unwrapping Institutional Change in Fragile Settings: Women Entrepreneurs Driving Institutional Pathways in Afghanistan. World Development, 83, 39-53. https://doi.org/10.1016/j.worlddev.2016.03.007

Roundy, P. T. (2017). "Small town" entrepreneurial ecosystems. Journal of Entrepreneurship in Emerging Economies, 9(3), 238-262. https://doi.org/10.1108/JEEE-09-2016-0040

Rubio-Bañón, A., \& Esteban-Lloret, N. (2016). Cultural factors and gender role in female entrepreneurship. Suma de Negocios, 7(15), 9-17.

https://doi.org/10.1016/j.sumneg.2015.12.002

Salimath, M. S., \& Cullen, J. B. (2010). Formal and informal institutional effects on entrepreneurship: a synthesis of nation-level research. International Journal of Organizational Analysis, 18(3), 358-385. https://doi.org/10.1108/19348831011062175

Samantroy, E., \& Tomar, J. S. (2018). Women Entrepreneurship in India: Evidence from Economic Censuses. Social Change, 48(2), 188-207. https://doi.org/10.1177/0049085718768898

Sambasivan, M., Abdul, M., \& Yusop, Y. (2009). Impact of personal qualities and management skills of entrepreneurs on venture performance in Malaysia: Opportunity recognition skills as a mediating factor. Technovation, 29(11), 798-805.

https://doi.org/10.1016/j.technovation.2009.04.002

Santos, S. C., Caetano, A., Baron, R., \& Curral, L. (2015). Prototype models of opportunity recognition and the decision to launch a new venture: Identifying the basic dimensions. International 
INTERNATIONAL JOURNAL OF ACADEMIC RESEARCH IN BUSINESS AND SOCIAL SCIENCES

Vol. 10, No. 5, May, 2020, E-ISSN: 2222-6990 @ 2020 HRMARS

Journal of Entrepreneurial Behaviour and Research, 21(4), 510-538.

https://doi.org/10.1108/IJEBR-04-2014-0058

Sarri, K. K. (2011). Mentoring female entrepreneurs: a mentors' training intervention evaluation. Journal of European Industrial Training, 35(7), 721-741.

https://doi.org/10.1108/03090591111160814

Shane, S., \& Nicolaou, N. (2015). Creative personality, opportunity recognition and the tendency to start businesses: A study of their genetic predispositions. Journal of Business Venturing, 30, 407-419. https://doi.org/10.1016/j.jbusvent.2014.04.001

Sharma, Y. (2013). Women Entrepreneur In India. IOSR Journal of Business and Management, 15(3), 09-14. https://doi.org/10.9790/487X-1530914

Singer, S., Amoros, J. E., \& Arreola, D. moska. (2015). Global Entrepreneurship Monitor 2014 report. In Global Entrepreneurship Research Association. https://doi.org/ISBN: 978-1-939242-05-1

Sivanesan, R. (2014). A comparative study on rural and urban women entrepreneurs - Prospects and challenges. International Journal of Research in Management and Business Studies, 1(3), 2834.

Suárez-Ortega, M., \& Gálvez-García, R. (2017). Motivations and Decisive Factors in Women's Entrepreneurship. A Gender Perspective in Education and Professional Guidance. Procedia Social and Behavioral Sciences, 237(June 2016), 1265-1271.

https://doi.org/10.1016/j.sbspro.2017.02.208

Urban, B., \& Kujinga, L. (2017). The institutional environment and social entrepreneurship intentions. International Journal of Entrepreneurial Behavior \& Research, 23(4), 638-655. https://doi.org/10.1108/IJEBR-07-2016-0218

Wang, Y. L., Ellinger, A. D., \& Wu, Y. C. J. (2013). Entrepreneurial opportunity recognition: An empirical study of R\&D personnel. Management Decision, 51(2), 248-266. https://doi.org/10.1108/00251741311301803

Wei, X., \& Wang, N. (2014). Research on the contents and structure of social support network for private entrepreneurs in transitional environment. 2009 International Conference on Information Management, Innovation Management and Industrial Engineering, ICIII 2009, 2, 94-97. https://doi.org/10.1109/ICIII.2009.181

Wellalage, N., \& Locke, S. (2017). Access to credit by SMEs in South Asia: do women entrepreneurs face discrimination. Research in International Business and Finance, 41(October 2016), 336346. https://doi.org/10.1016/j.ribaf.2017.04.053 